\title{
The Impact of Consumer Ethnocentrism on Purchase Intentions: Local Versus Foreign Brands
}

\author{
Mehrukh Salman*and Uswa Naeem**
}

\begin{abstract}
This study evaluates the impact of consumer constructs, including ethnocentrism, attitudes toward brands, and celebrity endorsement, on purchase intentions for beverages in Pakistan. A quantitative survey was administered to collect the data and a path analysis conducted to test the model. Based on a sample of 150 respondents, our results indicate a positive relationship between ethnocentrism and purchase intentions with respect to local brands. Moreover, ethnocentrism, attitudes toward brands, and celebrity endorsements all have a significant impact on purchase intentions for local brands.
\end{abstract}

Keywords: consumer ethnocentrism, celebrity endorsement, attitudes, purchase intentions.

JEL classification: M3, M31.

\section{Introduction}

This study aims to investigate the role of three consumer constructs-ethnocentrism, celebrity endorsement, and attitudes toward local and foreign brands-in influencing consumers' purchase decisions in Pakistan. The first construct, consumer ethnocentrism, determines how consumers compare local and foreign brands, and whether they favor one over the other. The second construct, which relates to consumer behavior, incorporates consumers' perception of and response to a particular brand. The third construct, celebrity endorsement, explains how "any individual who enjoys public cognition... uses this cognition on behalf of a consumer by appearing within an advertisement" (McCracken, 1989).

The strength of consumer attitudes can determine purchase intentions with respect to specific brands (Kim \&Park, 2013). On one hand, consumers quickly recognize and relate to local products, which they may perceive as being of better quality(Cayla \& Eckhardt, 2007;

\footnotetext{
* Teaching fellow, Lahore School of Economics.

${ }^{* *}$ Graduate student, Lahore School of Economics.
} 
Akram, Merunka, \&Akram,2011). On the other hand, in many developing countries, foreign brands are seen as status symbols (Bhardwaj, Park, \& Kim, 2011), giving them precedence over local brands.

The main focus of this study is to understand the impact of key consumer constructs on purchase intentions with respect to beverages in Pakistan. The beverage industry represents a range of popular and easily affordable products, and is characterized by heavy competition between foreign and local brands. The product categories we look at are tea and cola products. Specifically, we aim to identify:

A positive relationship between consumer ethnocentrism and attitudes toward local brands

The impact of consumer ethnocentrism on attitudes toward foreign products intentions.

How celebrity endorsement influences consumer purchase

Section 2 presents a literature review, Section 3 explains the methodology used, and Section 4 describes the data employed. Sections 5 and 6 discuss the results obtained, and Section 7 concludes the study.

\section{Literature Review}

Ethnocentrism as a sociological concept was defined by Sumner (1906) as the "view of things in which one's own group is the center of everything, and all others are scaled and rated with reference to it." This implies readily accepting similar cultural phenomena on the assumption that one's own culture is superior to others.

Shimp and Sharma (1987) have extended this concept to include consumer ethnocentrism (the present study's first construct). Consumer ethnocentric groups oppose the purchase of foreign products because they assume that it hurts the domestic economy in the form of loss of employment. Such groups see this as unpatriotic and assign a sense of morality to the choice between domestic and foreign products. Shimp and Sharma also see consumer ethnocentrism as a way of understanding purchase behavior among people from the same region or country in that it illustrates a sense of national identity. 
Kumar, Fair Hurst, and Kim (2011) argue that ethnocentric consumers focus on the positive attributes of local products and are liable to reject foreign products even if they know these are better than the former. Kayankand Eksi (2011) point out that highly ethnocentric consumers will forego even the opportunity to import foreign products (which they consider substandard) in order to support domestic ally produced brands.

Akram et al. (2011) note that, although consumer ethnocentrism is not necessarily generalized across different regions or countries, it remains an important tool for marketing managers to understand consumer preferences toward foreign and local products. Kumar et al. (2011) observe that highly ethnocentric consumers in developed countries prefer locally produced goods out of a moral obligation to reject foreign products.

The second construct, attitudes, comprise "a summary evaluation of a psychological object captured in such attribute dimensions as goodbad, harmful-beneficial, pleasant-unpleasant, and likeable-dislikeable" (Ajzen, 2001).Kim and Park (2013) divide consumer attitudes into cognitive and affective attitudes: the first reflects consumers' emotional attachment and response toward a product or brand; the second considers how consumers perceive a particular brand (Herrmann, Huber, Shao, \& Bao, 2007). Based on the studies cited above, we propose the following hypotheses:

$\mathrm{H}_{1 \mathrm{a}}$ : Consumer ethnocentrism has a positive relationship with attitudes toward local brands.

$\mathrm{H}_{1 \mathrm{~b}}$ : Consumer ethnocentrism has a negative relationship with attitudes toward foreign brands.

The wide range of choice among different brands and products can also be understood in terms of the choice between local and foreign goods (Batra et al., 2000).Akram et al. (2011) hold that, over time, developing countries have also begun to offer an extensive range of foreign products to the point that such brands have become "global." For our purposes, however, we use the term "foreign brand" instead to make a clear distinction between goods produced locally and overseas from the perspective of consumers in developing countries.

Local brands tend to represent local consumers and their particular culture or region (Cayla \& Eckhardt, 2007), while foreign brands may allow consumers to feel modern or socially superior. This 
perception can propel them to purchase foreign brands rather than local ones, sometimes regardless of quality standards (Kottak, 1990). Batra et al. (2000), for instance, believe that Indian consumers tend to prefer foreign brands because of the associated social prestige. Özsomer, Batra, Chattopadhyay, and terHofstede (2012) observe that the purchase of foreign products may reflect a sense of lower self-esteem among consumers in less economically developed cultures or countries. Thus, ethnocentrism clearly has a strong impact on attitudes toward local versus foreign products.

We study the third construct, purchase intention, in terms of how it is influenced by other factors, including ethnocentrism, attitudes toward foreign versus local products, and celebrity endorsement. Yoo, Donthu, and Lee (2000) define purchase intention as the practice of maintaining brand loyalty. In this context, we propose the following hypotheses:

$\mathrm{H}_{2}$ : Attitudes toward local brands (produced in Pakistan) have a positive impact on purchase intention.

$\mathrm{H}_{3}$ : Attitudes toward foreign brands (produced abroad) have a negative impact on purchase intention.

Lee, Kim, and Lee (2012) suggest that consumers' loyalty toward a specific brand depends on whether their cognitive and affective experiences of that brand are positive. Kim and Park (2013) argue that both types of response have an equal impact on purchase intention. Thus, both the rational and emotional aspects of consumer behavior determine purchase intentions (Hirschman, 1983).

Prestige, credibility, esteem, and quality are often associated with foreign or global brands (Batra et al., 2000; Johansson \& Ronkainen, 2005). Consumers take these into account when deciding whether to buy foreign products (Shimp \& Sharma, 1987). Bhardwaj et al.(2011) argue that consumers in developing countries show brand loyalty toward foreign products because they tend to associate these with better quality standards. Bhatt and Reddy (1998) support this observation based on a study of consumption patterns in developing countries, which shows that consumers associate the purchase of foreign products with social prestige.

Akram et al. (2011) suggest that domestic products are also perceived positively in terms of quality and prestige, but that this attitude varies from one culture to another. Batra et al. (2000) point out that ethnocentric consumers have negative attitudes toward foreign products. 
Shankarmahesh (2006) notes that ethnocentrism is one of the most important factors determining consumers' purchase intentions with respect to both foreign and local products. Han (1988) and Herche (1992) provide empirical evidence to indicate a strong and significant relationship between consumer ethnocentrism and purchase intention toward local products. Thus, our fourth hypothesis $\left(\mathrm{H}_{4}\right)$ is that consumer ethnocentrism among Pakistanis has a positive impact on their purchase intentions with respect to local brands.

The term brand is defined as a "symbol, sign, term, name, or a combination of these that recognize the services or products of an organization and differentiate it from services or products of other organizations" (Kotler \& Armstrong, 2007). Roozen and Claeys (2010) define a brand as "a seller's promise to deliver a specific set of features, benefits, and services consistently to the buyers."

In this context, endorsement refers to the "stamp of approval" that a celebrity gives to a product, service, or brand (Özsomer et al., 2012). Mehta (1994) suggests that consumers are attracted to brands that carry a celebrity endorsement. This has a positive impact on their purchase intentions relative to products endorsed by people who are not celebrities (Khatri, 2006). Solomon (2009) observes that consumers are likely to relate to the perceived social values of a physically attractive celebrity endorser, who represents a positive stereo type. Winterich, Grewal, and Gangwar (2012) point out that consumers' beliefs are more likely to be influenced by a positive advertisement, thus encouraging their purchase decisions.

Evans (1988) takes this further and suggests that, in some cases, consumers may remember the endorser more than the product being endorsed, which the author terms the "vampire eeffect." It is thus important to relate the celebrity's image to that of the brand, which goes beyond the attractiveness and credibility of the endorser. Debevec and Kernan (1984) find that attractive female models often yield better results in improving attitudes toward a brand compared to male models. When consumers buy a brand because it has been endorsed by a celebrity, they do so because it reflects their ideals and aspirations (McCracken, 1989).

Most consumer behavior literature suggests that trust worthinessisan essential attribute for a celebrity to be deemed credible. Consumers with a high degree of confidence in the endorser will be more motivated to buy the product. A celebrity's perceived "expertise" stems from how people gauge his or her awareness, experience, or skills, which 
in turn influences how consumers evaluate the quality of the product being endorsed. Therefore, individual perceptions of an endorser's expertise are positively correlated with consumers' purchase intentions. Our fifth hypothesis $\left(\mathrm{H}_{5}\right)$ is that celebrity endorsement has a positive impact on purchase intentions.

\section{Sample and Methodology}

We have used convenience sampling in this study. A total of 176 people attempted the survey questionnaire, of which 150 responses were usable. The participants comprised 40 percent $(n=60)$ men and 60 percent $(n=90)$ women. The sample was composed primarily of young people: about 75 percent $(n=113)$ were $20-29$ years old and about 10 percent $(n=15)$ were $50-59$ years old.

Most respondents belonged to middle-or high-income households: 36 percent $(n=45)$ fell under the high-income category, which implies they would have had greater economic independence and the ability to choose freely between foreign and local brands. Almost 75 percent $(n=112)$ were single and 23 percent $(n=35)$ were married. The sample can be safely categorized as well educated since almost 75 percent $(n=112)$ of the respondents had a Bachelor's degree while15 percent $(n=23)$ had completed their intermediate degree or ' $A$ ' levels.

A structured questionnaire based on a five-point Likert scale (where 1 = strongly disagree and 5 = strongly agree) was developed, avoiding open-ended questions, which respondents often omit.

We have selected two beverage categories-soft drinks and teain order to compare local brands with their foreign alternatives. The products were selected keeping in view their accessibility and affordability across all socioeconomic groups and age groups.

Figure 1 illustrates the study's conceptual framework. 


\section{Figure 1: Conceptual framework}

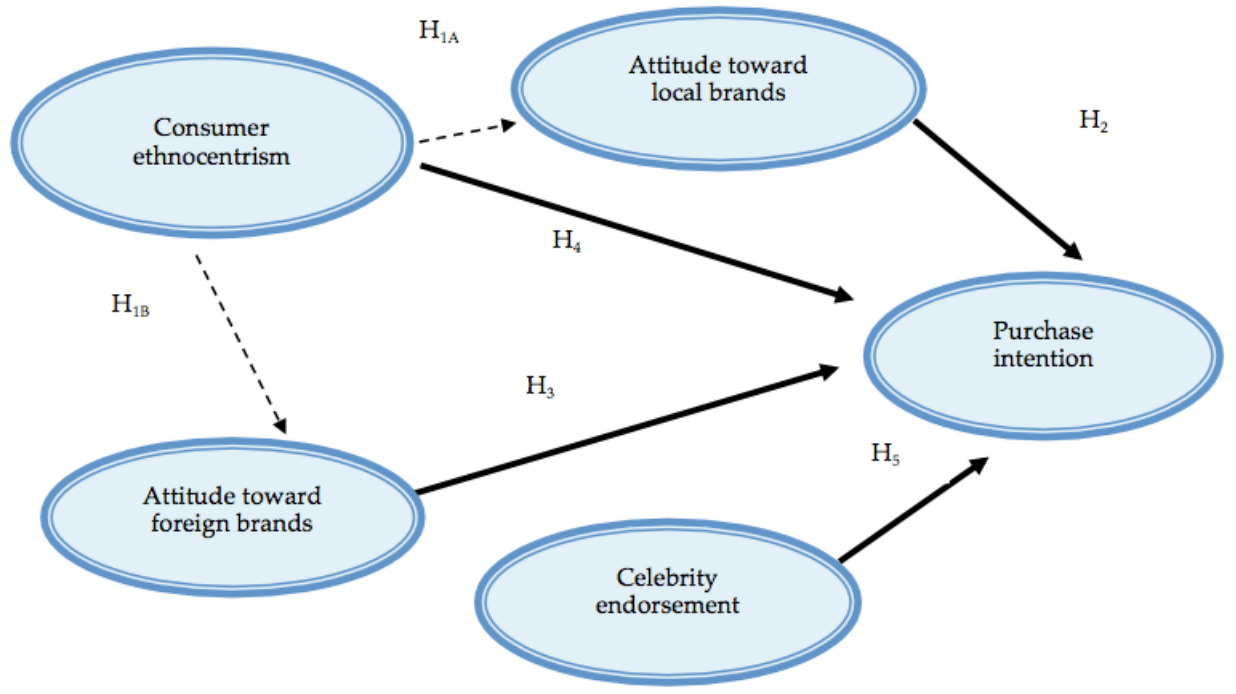

\section{Data}

All the scales used in this study are derived from previous research on consumer behavior. We apply several techniques to the data to validate our hypotheses and estimate the structural relations between the constructs. The quantitative analysis is carried out using AMOS: we conduct a path analysis to investigate the relationships between the variables. In order to check the validity of the scales used, we also carry out a confirmatory factor analysis (CFA).

The independent variables include consumer ethnocentrism (CE), attitudes toward local brands (ATL), attitudes toward foreign brands $(\mathrm{ATF})$, and celebrity endorsement (CBE). The dependent variable is purchase intention (PI) (see also Table 1). 
Table 1: Constitutive definition of variables

\begin{tabular}{|c|c|}
\hline Variable & Constitutive definition \\
\hline Ethnocentrism & $\begin{array}{l}\text { The view of things in which one's own group is the center } \\
\text { of everything, and all others are scaled and rated with } \\
\text { reference to it (Sumner, 1906). }\end{array}$ \\
\hline $\begin{array}{l}\text { Consumer } \\
\text { ethnocentrism }\end{array}$ & $\begin{array}{l}\text { The tendency to prefer domestic over foreign products } \\
\text { (Shimp \& Sharma, 1987). }\end{array}$ \\
\hline Attitude & $\begin{array}{l}\text { A summary evaluation of a psychological object captured in } \\
\text { such attribute dimensions as good-bad, harmful-beneficial, } \\
\text { pleasant-unpleasant, and likeable-dislikeable. }\end{array}$ \\
\hline $\begin{array}{l}\text { Attitude toward } \\
\text { local products }\end{array}$ & Produced locally and available in a specific region. \\
\hline $\begin{array}{l}\text { Attitude toward } \\
\text { foreign products }\end{array}$ & $\begin{array}{l}\text { Brands available to consumers under the same name in } \\
\text { multiple countries, generally with similar and centrally } \\
\text { coordinated marketing strategies. }\end{array}$ \\
\hline Cognitive & $\begin{array}{l}\text { Focus on attitude reflects brand perception in consumer's } \\
\text { mind (Kim\& Brandon, 2010). }\end{array}$ \\
\hline Affective & $\begin{array}{l}\text { Focus on attitude involves consumer's emotional response } \\
\text { to brand (Kim\& Brandon, 2010). }\end{array}$ \\
\hline $\begin{array}{l}\text { Celebrity } \\
\text { endorsement }\end{array}$ & $\begin{array}{l}\text { Any individual who enjoys public cognition and uses this } \\
\text { on behalf of consumers by appearing in an advertisement } \\
\text { (McCracken, 1989). }\end{array}$ \\
\hline $\begin{array}{l}\text { Purchase } \\
\text { intention }\end{array}$ & $\begin{array}{l}\text { Consumer practice of remaining loyal to the same brand } \\
\text { (Yoo et al., 2000). }\end{array}$ \\
\hline
\end{tabular}

Consumer ethnocentrismis measured on a 10-item CETSCALE modified by Klein, Ettenson, and Morris (1998), derived from the original 17-item CETSCALE constructed by Shimp and Sharma (1987).

Attitudes toward local and foreign brands are measured on a sixitem scale, where three items measure cognitive attitudes and three measure affective attitudes (see below). The scale is adapted from Kim and Park (2013). To compute ATL (ATF), we calculate the averages for attitudes toward the three local (foreign) brands and compute these as a single construct representing ATL (ATF).

\begin{tabular}{ll}
\hline Cognitive & I enjoy using this brand \\
& I like this brand \\
& This brand gives me pleasure \\
Affective & It provides good value for money \\
& I can trust this brand \\
& This brand is of good quality \\
\hline
\end{tabular}


Celebrity endorsement is measured on an eight-item scale adapted from Ohanian (1990).

Purchase intention is measured on a three-item scale derived from Riefler (2012), but modified to express PI with respect to local rather than foreign brands. The averages taken for the three product categories are used to compute a composite measure for the variable.

\section{Results}

We employ structural equation modeling to examine the model and test our proposed hypotheses. A three-step approach is used to confirm its reliability, uni-dimensionality, and validity (see Shah \&Goldstein, 2006). The items are loaded by means of CFA to evaluate the fit of the model. An iterative process is conducted to limit items where the loading is less than 0.4. As proposed by Hair et al. (2006), items are dropped only when this is deemed hypothetically sound and then deleted one by one until the model fit meets the required criteria. The alltime availability items have low loadings (less than 0.4 ) due to which the variables are eventually dropped. The analysis is conducted for CE, ATL, AFL, CBE, and PI.

In the first stage, we test for reliability using the average variance extracted (AVE) and for composite reliability using the standardized solutions in CFA (see Hult, Ketchen, \&Slater, 2004). A value of 0.7 or more is the generally accepted threshold for composite reliability along with an AVE of more than 0.5. Table 2 shows that the model's composite reliability ranges from 0.713 to 0.884 with an AVE of0.608 to 0.789 . This verifies the reliability of all the measures used.

The second step involves testing for uni-dimensionality in order to determine whether the items in the instrument belong to a single underlying construct (see Venkatraman \& Grant, 1986). The model fit is reasonable, indicating there is no uni-dimensionality (chi-square $=0.000$, $\mathrm{X} 2 / \mathrm{df}=1.87, \mathrm{CFI}=0.786, \mathrm{NFI}=0.855, \mathrm{TLI}=0.874$, and $\mathrm{RMSEA}=0.15)$.

Finally, we test for two types of validity: convergent and discriminant validity. Convergent validity is the extent to which several attempts are in agreement with the measures (Bagozzi \& Phillips, 1982). This is measured by the significance of each $t$-value of the measurement indicators (Chen, Paulraj, \& Lado, 2004; Sila \& Ebrahimpour, 2005). If the t-

values are greater than 2or if each item's coefficient is significant, then this confirms the model's convergent validity (Anderson \& Gerbing, 1988). 
Discriminant validity is the extent to which the constructs are dissimilar (John \& Reve, 1982). Thisis tested using Fornell and Larcker's (1981) recommended method in which the AVE is compared with the squared correlation of all the constructs. The AVE should be greater in value than the values of all the squared correlations. Table 2shows that the AVE values indicate the model is reliable, uni-dimensional, and valid.

Table 2: CFA results

\begin{tabular}{|c|c|c|c|c|}
\hline Item & $\begin{array}{c}\text { Consumer } \\
\text { ethnocentrism }\end{array}$ & Attitude & $\begin{array}{c}\text { Celebrity } \\
\text { endorsement }\end{array}$ & $\begin{array}{l}\text { Purchase } \\
\text { intention }\end{array}$ \\
\hline CE1 & 0.76 & & & \\
\hline CE2 & 0.45 & & & \\
\hline CE3 & 0.79 & & & \\
\hline CE4 & 0.87 & & & \\
\hline CE5 & 0.85 & & & \\
\hline CE6 & 0.62 & & & \\
\hline CE7 & 0.79 & & & \\
\hline CE8 & 0.67 & & & \\
\hline CE9 & 0.87 & & & \\
\hline CE10 & 0.78 & & & \\
\hline ATL/ATF1 & & 0.52 & & \\
\hline ATL/ATF2 & & 0.67 & & \\
\hline ATL/ATF3 & & 0.78 & & \\
\hline ATL/ATF4 & & 0.76 & & \\
\hline ATL/ATF5 & & 0.68 & & \\
\hline ATL/ATF6 & & 0.83 & & \\
\hline CBE1 & & & 0.76 & \\
\hline CBE2 & & & 0.46 & \\
\hline CBE3 & & & 0.59 & \\
\hline CBE4 & & & 0.78 & \\
\hline CBE5 & & & 0.76 & \\
\hline CBE6 & & & 0.82 & \\
\hline CBE7 & & & 0.78 & \\
\hline CBE8 & & & 0.77 & \\
\hline PI1 & & & & 0.67 \\
\hline PI2 & & & & 0.71 \\
\hline PI3 & & & & 0.78 \\
\hline AVE & 0.789 & 0.763 & 0.720 & 0.608 \\
\hline $\mathrm{Pc}($ reliability) & 0.816 & 0.713 & 0.884 & 0.764 \\
\hline
\end{tabular}

Source: Authors' calculations. 
We have generated five hypotheses on the basis of the literature review. The results for hypothesis $\mathrm{H}_{1 a}$ yield a coefficient of0.864, (indicating a positive relationship between the variables), with a p-value of less than 0.05.Given that the critical ratio for this relationship is 4.363, the hypothesis is deemed significant and can be accepted. Hypothesis $\mathrm{H}_{1 \mathrm{~b}}$, however, yields an insignificant result, indicating that CE is not related to ATF in our study. Thus, the hypothesis is rejected.

We test hypothesis $\mathrm{H}_{2}$ by establishing the relationship between ATL and PI. This yields a significant coefficient of 0.848 (indicating a positive relationship between the two variables). The $C R$ for this relationship is 9.114, and the hypothesis is, therefore, accepted.

We test hypothesis $\mathrm{H}_{3}$ based on the relationship between ATF and PI. There is a significant and negative relationship between the two variables (with a coefficient of -0.468). The CR is 3.205, with a significant p-value $(0.001<0.05)$. Thus, the hypothesis can be accepted.

In order to test hypothesis $\mathrm{H}_{4}$, we establish a relationship between $\mathrm{CE}$ and PI. The coefficient is 0.279 , indicating a positive relationship between the variables. The $C R$ is 1.555 with a significant $p$-value of $0.009<0.05$. This implies that the relationship between CE and PI is significant and the hypothesis can be accepted.

Finally, hypothesis $\mathrm{H}_{5}$ is tested by establishing a relationship between CBE and PI. This yields a coefficient of 0.336 (indicating a positive relationship).The CR is 2.984 with a p-value of $0.003<0.05$. Thus, $C E$ and PI have a significant relationship and we can accept the hypothesis.

Table 3: Hypothesis test results

\begin{tabular}{|c|c|c|c|c|c|c|}
\hline \multicolumn{3}{|c|}{ Hypothesis path } & Estimate & SE & CR & $\mathbf{P}$ \\
\hline $\mathrm{H}_{1 \mathrm{a}} \mathrm{ATL}$ & $<--$ & $\mathrm{CE}$ & 0.864 & 0.198 & 4.363 & $* * *$ \\
\hline $\mathrm{H}_{1 \mathrm{~b}} \mathrm{ATF}$ & $<--$ & $\mathrm{CE}$ & 0.055 & 0.117 & 0.471 & 0.638(insignificant) \\
\hline $\mathrm{H}_{2} \mathrm{PI}$ & $<--$ & ATL & 0.848 & 0.093 & 9.114 & $* * *$ \\
\hline $\mathrm{H}_{3} \mathrm{PI}$ & $<--$ & ATF & -0.468 & 0.146 & 3.205 & 0.001 \\
\hline $\mathrm{H}_{4} \mathrm{PI}$ & $<--$ & $\mathrm{CE}$ & 0.279 & 0.180 & 1.555 & 0.009 \\
\hline $\mathrm{H}_{5} \mathrm{PI}$ & $<--$ & CBE & 0.336 & 0.112 & 2.984 & 0.003 \\
\hline
\end{tabular}

Note: ${ }^{* * *} \mathrm{p}<0.01,{ }^{* *} \mathrm{p}<0.05,{ }^{*} \mathrm{p}<0.10$

Source: Authors' calculations.

Table 4 gives the goodness-of-fit measures, which indicate that the model has an adequate fit. 
Table 4: Model fit

\begin{tabular}{lcc}
\hline Goodness of fit & Criterion & Value \\
\hline Chi-square & & 0.76 \\
X2/df & $1-3$ & 1.56 \\
CFI & $>0.80$ & 0.84 \\
NFI & $>0.80$ & 0.95 \\
IFI & $>0.80$ & 0.82 \\
TLI & $>0.80$ & 0.81 \\
RMSEA & $<0.10$ & 0.05 \\
\hline
\end{tabular}

Source: Authors' calculations.

\section{Discussion}

The results for $\mathrm{H}_{1 \mathrm{a}}$ are consistent with those of previous studies: we find that consumer ethnocentrism has a strong and positive relationship with attitudes toward local brands. Over time, a number of new competitors have entered the Pakistani market for local beverages, signaling the strong consumer demand for local brands. Our sample demonstrates a high ethnocentric tendency. However, we reject hypothesis $\mathrm{H}_{1 \mathrm{~b}}$ because there is an insignificant relationship between consumer ethnocentrism and attitudes toward foreign brands. This result contradicts previous studies such as Kumar et al. (2011), Riefler (2012), Özsomer et al. (2012), Shimp and Sharma (1987), and Kottak (1990).

The path analysis does not support $\mathrm{H}_{1 \mathrm{~b}}$. This might reflect the growing impact of globalization where consumers in Pakistan prefer domestically produced goods, but have also become more aware of foreign brands and of the social status associated with these. Studies conducted in developed regions such as North America find that consumers generally have a more positive perception of domestic over foreign products (Kumar et al., 2011).However, researchers such as Punyatoya (2013) hold that ethnocentrism does not necessarily help study consumer attitudes toward foreign products.

Our results show that attitudes toward local brands have a significant and positive impact on purchase intentions with respect to local beverages, presumably because consumers relate better to local brands. Akram et al. (2011) suggest that domestic products are perceived positively in terms of quality and prestige, although this attitude varies from one culture to another. 
Attitudes toward foreign brands do not seem to explain consumers' purchase intentions with respect to local beverage brands. Bhardwaj et al.(2011)argue that consumers show brand loyalty toward foreign products in developing countries where such products are associated with better quality standards. This might imply that, overtime, the concept of "branded" goods has emerged due to the tough competition between local and foreign products.

The results of the path analysis are in line with previous studies such as Özsomer et al. (2012), where consumer ethnocentrismis shown to have a positive impact on purchase intentions with respect to local brands. Moreover, our results indicate a fairly strong level of consumer ethnocentrism. Finally, celebrity endorsement also has a positive impact on purchase intention. This result is in line with studies such as Mehta (1994), Khatri (2006), and McCracken (1989).

\section{Conclusion}

The purpose of this study was to analyze the impact of consumer ethnocentrism on attitudes toward foreign and local brands, as well as the impact of celebrity endorsement on purchase intentions in the beverages market. Overall, we have found that consumers with higher levels of ethnocentrism and favorable attitudes toward local brands are more likely to purchase local rather than foreign products.

In this context, managers for local brands should focus on local preferences so that consumers maintain such consumption patterns. Promoting the idea of national identity among consumers where product preferences are concerned could help effectively retain and increase market share and tackle foreign competition. Local brands that reflect local values are likely to do well in this industry (Ger, 1999). Managers for foreign brands, on the other hand, could try promoting their products as being prestigious and modern.

This model could be replicated and extended to compare ethnocentrism and attitudes between urban and rural consumers and between different cultures within developing countries. This would take into account Shimp and Sharma's (1987) observation that consumer behavior, values, beliefs, and consumption patterns tend to change with time and income. Moreover, this study has focused on a limited number of brands within the beverages market. Future studies could test the model with respect to other local and global brands in other product categories, such as electronics. 


\section{References}

Ajzen, I. (2001). Nature and operation of attitudes. Annual Review of Psychology, 52, 27-58.

Akram, A. M., Merunka, D., \& Akram, M. S. (2011). Perceived brand globalness in emerging markets and the moderating role of consumer ethnocentrism. International Journal of Emerging Markets, 6(4), 291-303.

Anderson, W. T., \& Cunningham, W. H. (1972). Gauging foreign product promotion. Journal of Advertising Research, 12(1), 29-34.

Anderson, J.C., \& Gerbing, D.W. (1988). Structural equation modeling in practice: A review and recommended two-step approach. Psychological Bulletin, 103(3), 411-423.

Bagozzi, R.P., \&Phillips, L.W. (1982). Representing and testing organizational theories: A holistic construal. Administrative Science Quarterly, 27(3), 459-489.

Balabanis, G., Diamantopoulos, A., \&Mueller, R. (2001). The impact of nationalism, patriotism and internationalism on consumer ethnocentric tendencies. Journal of International Business Studies, 32(1), 157-175.

Batra, R., Ramaswamy, V., Alden, D. L., Steenkamp, J.-B., \& Ramachander, S. (2000). Effects of brand local and nonlocal origin on consumer attitudes in developing countries. Journal of Consumer Psychology, 9(2), 83-95.

Bhardwaj, V., Park, H., \&Kim, Y.-K. (2011). The effect of Indian consumers' life satisfaction on brand behavior toward a US global brand. Journal of International Consumer Marketing, 23, 105-116.

Bhatt, S. A., \&Reddy, S. K. (1998). Symbolic and functional positioning of brands. Journal of Consumer Marketing, 15(1), 32-43.

Cayla, J., \& Eckhardt, G. M. (2007). Asian brands without borders: Regional opportunities and challenges. International Marketing Review, 24(4), 444-456. 
Chen, I.J., Paulraj, A., \& Lado, A.A. (2004). Strategic purchasing, supply management, and firm performance. Journal of Operations Management, 22(5), 505-523.

Debevec, K., \& Kernan, J. B. (1984). More evidence on the effects of a presenter's attractiveness: Some cognitive, affective, and behavioral consequences. In T. C. Kinnear (Ed.), NA - Advances in consumer research (vol. 11, pp. 127-132). Provo, UT: Association for Consumer Research.

Evans, R. B. (1988). Production and creativity in advertising. London: Pitman.

Fornell, C., \& Larcker, D.F. (1981). Evaluating structural equation models with unobservable variables and measurement error. Journal of Marketing Research, 18(1), 39-50.

Ger, G.(1999). Localizing in the global village: Local firms competing in global markets. California Management Review, 41(4), 64-84.

Hair, J.F., Black, W.C., Babin, B.J., Anderson, R.E., \& Tatham, R.L. (2006). Multivariate data analysis (6th ed.).Upper Saddle River, NJ: Prentice Hall.

Han, C.M. (1988).The role of consumer patriotism in the choice of domestic versus foreign products. Journal of Advertising Research, $28,25-32$.

Herche, J. (1992). A note on the predictive validity of the CETSCALE. Journal of the Academy of Marketing Science, 20(3), 261-264.

Herrmann, A., Huber, F., Shao, A. T., \& Bao, Y. (2007). Building brand equity via product quality. Total Quality Management, 18(5), 531-544.

Hirschman, E. C. (1983).Aesthetics, ideologies and the limits of the marketing concept. Journal of Marketing, 47(3), 45-55.

Hult, G.T., Ketchen, D.J., \& Slater, S.F. (2004). Information processing, knowledge development, and strategic supply chain performance. Academy of Management Journal, 47(2), 241-253.

Johansson, J. K., \& Ronkainen, I. A. (2005).The esteem of global brands. Journal of Brand Management, 12(5), 339-354. 
John, G., \& Reve, T. (1982). The reliability and validity of key informant data from dyadic relationships in marketing channels. Journal of Marketing Research, 19(4), 517-524.

Kayank, R., \& Eksi, S. (2011). Ethnocentrism, religiosity, environmental and health consciousness: Motivators for anti-consumers. Eurasian Journal of Business and Economics, 4(8), 31-50.

Khatri, P. (2006). Celebrity endorsement: A strategic promotion perspective. Indian Media Studies Journal, 1(1), 25-37.

Kim, E. Y., \&Brandon, L. (2010). Modeling brand equity for lifestyle brand extensions: A strategic approach into Generation Y vs. baby boomer. Journal of Global Academy of Marketing Science, 20(1), 35-48.

Kim, E. Y., \& Park, K. (2013). Marketing mix elements influencing brand attitude strength: Global vs. domestic SPA brands. Journal of Global Scholars of Marketing Science, 23(3), 263-281.

Klein, J. G., Ettenson, R., \&Morris, M. D. (1998). The animosity model of foreign product purchase: An empirical test in the People's Republic of China. Journal of Marketing, 62(1), 89-100.

Kotler, P., \&Armstrong, G. (2007). Principles of marketing. Upper Saddle River, NJ: Prentice Hall.

Kottak, C. P. (1990).Prime-time society: An anthropological analysis of television and culture. Belmont, CA: Wadsworth.

Kumar, A., Fairhurst, A., \&Kim, Y.-K. (2011). Ethnocentric tendencies of Indian consumers: Impact on preference for domestic versus foreign products. International Review of Retail, Distribution and Consumer Research, 21(4), 323-341.

Lee, H. S., Kim, H. J., \& Lee, J. G. (2012). A study on the influence of SPA (specialty store retailer of private label apparel) brand buying experience on brand loyalty. Academy of Customer Satisfaction Management, 14, 101-123.

Lindquist, J. D., Vida, I., Plank, R. E., \& Fairhurst, A. (2001). The modified CETSCALE: Validity tests in the Czech Republic, Hungary and Poland. International Business Review, 10(5), 505-516. 
McCracken, G. (1989). Who is the celebrity endorser? Cultural foundations of the endorsement process. Journal of Consumer Research, 16(3), 310-321.

Mehta, A. (1994). How advertising response modeling (ARM) can increase ad effectiveness. Journal of Advertising Research, 34(3), 62-74.

Ohanian, R. (1990). Construction and validation of a scale to measure celebrity endorsers' perceived expertise, trustworthiness and attractiveness. Journal of Advertising, 19(3), 39-52.

Özsomer, A., Batra, R., Chattopadhyay, A., \& terHofstede, F. (2012).A global brand management roadmap. International Journal of Research in Marketing, 29(1), 1-4.

Punyatoya, P. (2013). Consumer evaluation of brand extension for global and local brands: The moderating role of product similarity. Journal of International Consumer Marketing, 25, 98-215.

Riefler, P. (2012). Why consumers do (not) like global brands: The role of globalization attitude, GCO and global brand origin. International Journal of Research in Marketing, 29(1), 25-34.

Roozen, I., \& Claeys, C. (2010). The relative effectiveness of celebrity endorsement for print advertisement. Review of Business and Economics, 55(1), 76-89.

Shah, R., \&Goldstein, S.M. (2006). Use of structural equation modeling in operations management research: Looking back and forward. Journal of Operations Management, 24(2), 148-169.

Shankarmahesh, M. N. (2006). Consumer ethnocentrism: An integrative review of its antecedents and consequences. International Marketing Review, 23(2), 146-172.

Shimp, T. A., \& Sharma, S. (1987). Consumer ethnocentrism: Construction and validation of the CETSCALE. Journal of Marketing Research, 24(3), 280-289.

Sila, I., \& Ebrahimpour, M. (2005). Critical linkages among TQM factors and business results. International Journal of Operations and Production Management, 25(11), 1123-1155. 
Solomon, M. R. (2009).Consumer behavior: Buying, having, and being. Upper Saddle River, NJ: Prentice Hall.

Sumner, W. G. (1906). Folkways: A study of the sociological importance of usages, manners, customs, mores, and morals. New York, NY: Ginn.

Venkatraman, N., \&Grant, J.H. (1986). Construct measurement in organizational strategy research: A critique and proposal. Academy of Management Review, 11(1), 71-87.

Winterich, K. P., Grewal, R., \& Gangwar, M. (2012). When celebrities count: Power distance as an explanation for the popularity of celebrity endorsements in emerging markets. Unpublished manuscript. Retrieved from http://www.isb.edu/faculty/Manish_Gangwar/Celebrity Endorsments in Emerging Markets.pdf

Yoo, B., Donthu, N., \&Lee, S. (2000). An examination of selected marketing mix elements and brand equity. Journal of the Academy of Marketing Science, 28(2), 195-211. 